Syntax Fusion : Jurnal Nasional Indonesia

p-ISSN: -

e-ISSN : 2775-4440

Vol. 1, No. 8, Agustus 2021

\title{
ANALISIS MODAL KERJA, LIKUIDITAS, DAN LEVERAGE TERHADAP PROFITABILITAS PERUSAHAAN (STUDI KASUS PADA PERUSAHAAN MANUFAKTUR PULP DAN KERTAS DI INDONESIA)
}

\section{Bagas Putra Pradana}

Institut Teknologi Telkom Surabaya (ITTS)

Email: bagasdana@ittelkom-sby.ac.id

\begin{abstract}
Abstrak
Jurnal ini hendak mengetahui faktor-faktor yang bisa mempengaruhi profitabilitas pada perusahaan manufaktur sub sektor pulp dan kertas di BEI tahun 2012-2017. Sampel yang digunakan dalam penelitian ini sebanyak 7 perusahaan dengan teknik purposive sampling. Teknik analisis data yang digunakan adalah analisis regresi dengan menggunakan software SPSS 16.0. Nilai Adjusted $R^{2}$ sebesar 0,183, artinya bahwa perubahan variabel independen yaitu perputaran modal usaha, rasio likuiditas (current ratio) dan financial leverage mampu memberikan kontribusi sebesar 18,3\% terhadap perubahan variabel dependen yaitu profitabilitas (ROA) sedangkan sisanya dijelaskan oleh variabel lain. Hasil Uji F menunjukan bahwa perputaran modal usaha, rasio likuiditas dan financial leverage secara simultan berpengaruh signifikan terhadap profitabilitas (ROA). Sedangkan hasil Uji t menunjukan variabel rasio likuiditas (current ratio) secara parsial berpengaruh signifikan terhadap profitabilitas, sedangkan variabel perputaran modal usaha dan financial leverage tidak memiliki pengaruh yang signifikan terhadap profitabilitas (ROA).
\end{abstract}

Kata Kunci: Current Ratio (CR), Financial Leverage (LEV), Return on Assets (ROA), Working Capital Turnover (WCT).

\section{Pendahuluan}

Salah satu tujuan dari sebuah perusahaan adalah untuk menbisakan laba yang maksimal. Untuk mencapai tujuan tersebut diperlukan tata kelola dan manajemen yang baik dan terukur. Pengukuran tingkat efektifitas manajemen yang ditunjukkan oleh kebisaan sebuah perusahaan untuk menbisakan laba dengan cara memaksimalkan penjualan, total aktivitas maupun modal sendiri, bisa dikerjakan dengan memahami seberapa banyak rasio pada profitabilitas yang dipunyai. Setiap kegiatan yang dilakukan oleh sebuah perusahaan akan selalu membutuhkan dana, entah untuk membiayai pekerjaan operasional sehari-hari para pekerja maupun untuk membiayai investasi jangka yang panjangnya. Uang yang dibutuhkan untuk bisa melangsungkan pekerjaan 
operasional sehari-hari disebut dengan modal usaha. Modal usaha ini akan terus berputar di dalam perusahaan. Menurut Riyanto (2013:61), modal usaha adalah modal yang mesti tetap ada pada perusahaan, supaya bisa melakukan fungsinya atau dengan kata lain, modal usaha yang secara terus-menerus dibutuhkan untuk kelancaran usaha. Oleh karena itu, kesilapan dalam mengelola modal usaha bisa mengakibatkan kegiatan usaha bisa terhambat, atau terhenti sama sekali.

Modal usaha memiliki arti yang begitu penting supaya perusahaan bisa beroperasi secara terus-menerus dengan prinsip kesinambungan. Faktor modal usaha harus menbisa perhatian yang khusus agar pembelanjaan modal usaha bisa dilakukan dengan tepat waktu. Efisien atau tidaknya pembelanjaan modal usaha bisa memengaruhi likuiditas perusahaan, dan besar kecilnya likuiditas perusahaan bisa memengaruhi profitabilitas perusahaan. Efisiensi modal usaha bisa diukur dengan melihat tingkat perputaran modal usaha (working capital turnover), yaitu dengan membandingkan antara total penjualan dengan jumlah kelebihan aktiva lancar diatas utang lancarnya.

Likuiditas perusahaan menunjukkan kemampuan untuk membayar kewajiban finansial dalam jangka pendek tepat pada waktunya. Likuiditas perusahaan ditampakkan oleh besar kecilnya aktiva lancar, yaitu aktiva yang mudah diubah menjadi kas yang meliputi kas, surat berharga, piutang dan persediaan (Sartono, 2011:116). Kemampuan perusahaan untuk memenuhi kewajiban keuangan yang berhubungan dengan pihak luar perusahaan atau kreditur dinamakan "likuiditas badan usaha", sedang yang berhubungan dengan pihak intern atau proses produksi, dinamakan "likuiditas perusahaan". Perusahaan dihadapkan pada masalah adanya pertukaran (trade off) antara faktor likuiditas dan profitabilitas. Jika perusahaan memutuskan menetapkan modal usaha dalam jumlah yang besar, kemungkinan tingkat likuiditas akan terjaga namun kesempatan untuk memperoleh laba yang besar akan menurun yang pada akhirnya berdampak pada menurunnya profitabilitas.

Sebaliknya jika perusahaan ingin memaksimalkan profitabilitas, kemungkinan bisa mempengaruhi tingkat likuiditas perusahaan. Semakin tinggi likuiditas, maka semakin baik posisi perusahaan di mata kreditur. Menurut Sartono (2011:116), semakin tinggi current ratio berarti semakin besar kemampuan perusahaan untuk memenuhi kewajiban finansial jangka pendeknya. Oleh karena terbisa kemungkinan yang lebih besar bahwa perusahaan akan bisa membayar kewajibannya tepat pada waktunya. Di lain pihak ditinjau dari segi sudut pemegang saham, likuiditas yang tinggi tak selalu menguntungkan karena berpeluang menimbulkan dana-dana yang menganggur yang sebenarnya bisa digunakan untuk berinvestasi dalam proyek-proyek yang menguntungkan perusahaan. Sehingga untuk mengetahui tingkat likuiditas serta seberapa besar modal usaha yang dialokasikan perusahaan untuk operasi perusahaan, bisa digunakan rasio lancar atau yang lebih dikenal dengan current ratio.

Jika perusahaan tidak mampu menghasilkan profitabilitas yang cukup, maka perusahaan tersebut tidak akan mampu untuk menjaga kelangsungan usahanya. Oleh karena itu, perusahaan harus mencari sumber dana yang berasal dari luar perusahaan untuk menjaga kelangsungan usahanya. Pemenuhan kebutuhan dana yang berasal dari 
luar perusahaan bisa diperoleh dari meminjam dana kepada pihak kreditur seperti bank, lembaga keuangan bukan bank, atau bisa pula perusahaan menerbitkan saham dan obligasi untuk ditawarkan kepada masyarakat. Pemenuhan sumber dana melalui utang (pinjaman) akan mempengaruhi tingkat leverage perusahaan, karena leverage merupakan rasio yang digunakan untuk mengukur seberapa jauh perusahaan menggunakan utang. Penggunaan financial leverage yang makin tinggi mengakibatkan biaya modal tetapnya tinggi dan perusahaan harus berusaha agar memperoleh tambahan penbisaan yang lebih tinggi daripada biaya tetapnya. Penggunaan financial leverage yang makin tinggi mengakibatkan risiko finansial juga meningkat. Dengan demikian semakin tinggi rasio leverage maka akan semakin tinggi pula risiko finansialnya (financial risk) (Sartono, 2011:267).

Financial leverage adalah penggunaan sumber dana yang memiliki beban tetap dengan harapan bahwa akan memberikan tambahan keuntungan yang lebih besar daripada beban tetapnya sehingga akan meningkatkan keuntungan yang tersedia bagi pemegang saham (Sartono, 2011:263). Riyanto (2013:203), menyatakan bahwa perimbangan antara utang dengan modal akan mempunyai efek terhadap tingkat leverage perusahaan yang bersangkutan, setiap tambahan utang akan selalu menurunkan tingkat solvabilitasnya dan setiap penambahan modal sendiri akan menaikkan tingkat solvabilitasnya. Berhubung dengan itu maka apabila suatu perusahaan dalam memenuhi kebutuhan modalnya hanya berdasarkan pada pertimbangan solvabilitasnya saja, maka pemenuhan modalnya haruslah selalu atau sebagian besar dipenuhi dengan modal sendiri. Karena makin besarnya modal usaha maka semakin tinggi tingkat solvabilitasnya yang berdampak pada peningkatan profitabilitas.

Perusahaan manufaktur merupakan perusahaan industri pengolahan bahan baku menjadi barang setengah jadi atau barang jadi lalu menjualnya kepada konsumen. Perusahaan pulp dan kertas adalah salah satu perusahaan manufaktur yang mecatatkan saham nya di BEI. Menurut Kementrian Perindustrian, Perusahaan manufaktur sub sektor pulp dan kertas merupakan sektor industri unggulan yang terus dipacu pengembangannya oleh Pemerintah dan memiliki potensi pertumbuhan yang cukup signifikan. Indonesia merupakan produsen kertas peringkat ke-6 dan untuk pulp menempati peringkat ke-9 di dunia. Industri ini memiliki tingkat pertumbuhan yang cukup tinggi dan bisa bertahan dalam jangka panjang.

Berdasarkan penjabaran di atas, maka bisa disimpulkan tujuan yang hendak diperoleh dari penelitian ini adalah untuk (1) menganalisis pengaruh perputaran modal usaha (working capital turnover) terhadap profitabilitas (ROA), (2) menganalisis pengaruh rasio likuiditas terhadap profitabilitas (ROA), (3) menganalisis pengaruh rasio financial leverage terhadap profitabilitas (ROA), dan (4) menganalisis pengaruh perputaran modal, rasio likuiditas dan financial leverage secara bersama-sama terhadap profitabilitas (ROA). 


\section{Metode Penelitian}

Penelitian ini termasuk dalam jenis penelitian asosiatif yang bertujuan untuk mengetahui hubungan antara dua variable atau lebih. Penelitian ini akan berfungsi untuk menjelaskan, meramalkan dan mengontrol suatu gejala. Oleh karena itu, dalam penelitian ini nantinya akan dijelaskan mengenai adanya hubungan interaktif atau timbal balik antara variable yang akan diteliti dan sejauh mana hubungan tersebut saling mempengaruhi. Teknik pengambilan sampel dalam penelitian ini menggunakan metode pusposive sampling, yaitu teknik penentuan sampel dengan pertimbangan tertentu (Sugiyono, 2017:122).

Jenis data yang digunakan dalam penelitian ini adalah data kuantitatif. Data kuantitatif adalah data yang berbentuk angka, atau data kualitatif yang diangkakan. Sedangkan sumber data yang digunakan dalam penelitian ini adalah data sekunder. Data sekunder mengacu pada informasi yang dikumpulkan dari sumber yang telah ada. Data sekunder yang dipakai dalam penelitian ini merupakan laporan keuangan perusahaan pulp dan kertas yang terdaftar di Bursa Efek Indonesia (BEI) tahun 2012- 2017 yang diperoleh dari website BEI di www.idx.co.id.

Terbisa dua variabel yang digunakan dalam penelitian ini yaitu variabel dependen (Y) dan variabel independen (X). Variabel dependen (terikat) adalah variabel yang dipengaruhi atau yang menjadi akibat, karena adanya variabel bebas (Sugiyono, 2017:61). Adapun variabel dependen dalam penelitian ini adalah profitabilitas yang diukur dengan Return On Investment $(\mathrm{ROI})=\mathrm{Y}$.

Variabel independen (bebas) adalah variabel yang mempengaruhi atau yang menjadi sebab atau timbulnya variabel terikat (Sugiyono, 2017:61). Adapun variabel independen dalam penelitian ini adalah efisiensi modal usaha yang diukur dengan WCT (X1), likuiditas yang diukur dengan $\mathrm{CR}$ (X2), dan financial leverage yang diukur dengan DAR (X3).

Metode analisis data yang digunakan dalam penelitian ini adalah analisis regresi linier berganda yang digunakan untuk menguji pengaruh dua atau lebih variabel independen terhadap satu variabel dependen (Imam, 2013:13). Selain itu juga dilakukan uji asumsi klasik yang digunakan untuk menguji apakah model regresi benar-benar menunjukkan hubungan yang signifikan dan representatif yang terdiri dari: Uji Autokorelasi, Uji Normalitas, Uji Multikolinearitas, dan Uji Heterokedastisitas; serta dilakukan Pengujian Determinasi dan Pengujian Hipotesis yang terdiri dari uji F dan uji t. Uji F digunakan untuk mengetahui pengaruh variabel independen terhadap variabel dependen secara simultan. Uji t digunakan untuk mengetahui pengaruh variabel independen terhadap variabel dependen secara parsial.

\section{Hasil dan Pembahasan}

Hasil Hasil uji regresi berganda dalam penelitian ini adalah sebagai berikut:

\section{Hasil Uji Regresi Linier Berganda}




\begin{tabular}{|l|l|l|l|l|}
\hline Variabel & $\begin{array}{c}\text { Unstandar } \\
\text { dized } \\
\text { Coefficient } \\
\mathrm{s}\end{array}$ & $\begin{array}{c}\text { Standardi } \\
\text { zed } \\
\text { Coefficie } \\
\text { nt } \\
\text { Beta }\end{array}$ & $\mathrm{t}$ & Sig. \\
\hline (Constant) & 7.742 & & 2.614 & .013 \\
\hline WCTOR & .000 & -.008 & -.057 & .955 \\
\hline LEV & -5.050 & -.144 & -.978 & .334 \\
\hline CR & -3.697 & -.430 & -2.914 & .006 \\
\hline
\end{tabular}

Sumber: Data sekunder yang diolah, 2018

Berdasarkan tabel diatas bisa dibentuk model regresi sebagai berikut:

$\mathrm{Y}=7.742+0.000 \mathrm{X}_{1}-3.697 \mathrm{X}_{2}-5.05 \mathrm{X}_{3}$

Hasil pengujian diatas menunjukkan bahwaWCT tidak mempunyai pengaruh sama sekali terhadap ROA. Variabel CR dan LEV memiliki pengaruh yang berbading terbalik terhadap variabel ROA karena memiliki nilai koefisien yang negatif. Diketahui nilai t tabel sebesar 2.024, dari tabel diatas bisa dikehatui bahwa secara parsial WCT dan LEV tidak berpengaruh terhadap ROA. Variabel CR berpengaruh terhadap ROA karena besar nilai t hitung adalah $-2.914<-2.024 \mathrm{t}$ tabel.

\begin{tabular}{|c|c|c|c|c|c|}
\multicolumn{1}{|c|}{ Hasil Uji F } \\
\hline Model & $\begin{array}{c}\text { Sum of } \\
\text { Squares }\end{array}$ & df & $\begin{array}{c}\text { Mean } \\
\text { Square }\end{array}$ & F & Sig. \\
\hline Regression & 221.073 & 3 & 73.691 & 4.057 & .014 \\
Residual & 690.238 & 38 & 18.164 & & \\
Total & 911.311 & 41 & & & \\
\hline
\end{tabular}

Hasil uji simultan, diketahui nilai $F$ tabel adalah 2,85. Hasil pengujian menunjukkannilai F hitung sebesar 4.057. Hal ini berartivariabel WCT, CR dan LEV secara bersama-sama berpengaruh terhadap profitabilitas perusahaan manufaktur sub sektor pulp dan kertas.

Hasil Uji Koefisien Determinasi

\begin{tabular}{|c|c|c|c|c|}
\hline Model & $\mathrm{R}$ & $\mathrm{R}$ \\
Square & $\begin{array}{c}\text { Adjusted } \\
\mathrm{R} \\
\text { Square }\end{array}$ & Std Error \\
\hline 1 & .493 & .243 & .183 & 4.26194 \\
\hline
\end{tabular}

Nilai Adjusted $R$ Square adalah sebesar0.183, hal ini menunjukkan bahwa variabeldependen yaitu WCT, CR dan LEV menjelaskan variabel ROA sebesar 18,3\% dan sisanya $81,7 \%$ dijelaskan oleh variabel lainnya yang tidak digunakan dalam penelitian ini.

\section{Pengaruh Perputaran Modal usaha Terhadap Profitabilitas}


Hasil Penelitian ini menunjukkan bahwa variabel WCT tidak berpengaruh terhadap profitabilitas perusahaan manufaktur sub sektor pulp dan kertas. Modal usaha diartikan sebagai investasi yang ditanamkan dalam aktiva lancar atau aktiva jangka pendek, seperti kas, bank, surat- surat berharga, piutang, persediaan, dan aktiva lancar lainnya. Working capital turnover dalam suatu perusahaan dipengaruhi oleh modal usaha (aktiva lancar dan hutang lancar) dalam menghasilkan penjualan. Semakin tinggi volume penjualan yang dihasilkan maka modal usaha berputar semakin cepat, sehingga modal cepat kembali ke perusahaan yang disertai dengan keuntungan yang tinggi pula, adanya keuntungan yang tinggi akan menyebabkan tingkat profitabilitas (ROA) perusahaan juga meningkat. Akan tetapi, penelitian pada perusahaan sampel menunjukkan bahwa tidak adanya pengaruh dari perputaran modal usaha terhadap tingkat profitabilitas (ROA) karena skor regresi yang menunjukkan angka 0,000. Peningkatan penjualan yang bisa dicapai tidak selalu mengakibatkan laba yang dihasilkan menjadi meningkat. Hal ini disebabkan oleh tingginya beban pokok penjualan.

Kenaikan beban pokok penjualan yang lebih tinggi daripada pertumbuhan penjualan yang dialami oleh beberapa perusahaan sampel menyebabkan laba yang dihasilkan menjadi rendah dan mengakibatkan terjadinya penurunan tingkat profitabilitas, sehingga tingkat penjualan yang tinggi tidak bisa meningkatkan laba atau profitabilitas perusahaan. Perusahaan sebaiknya bisa meningkatkan pengelolaan modal usahanya secara efisien, selain itu perusahaan juga harus menekan beban pokok penjualan sehingga bisa mencapai keuntungan yang diinginkan dan bisa meningkatkan profitabilitas secara signifikan.

Hal ini sesuai dengan penelitian dari Iskandar dan Darlis (2014) yang menyatakan bahwa modal usaha tidak berpengaruh terhadap profitabilitas. Hasil dari penelitian ini tidak mendukung hasil dari penelitian A. Wibowo dan S. Wartini (2012), yang menyatakan bahwa modal usaha berpengaruh terhadap profitabilitas.

\section{Pengaruh Rasio Likuiditas Terhadap Profitabilitas}

Hasil Penelitian ini menunjukkan bahwa variabel rasio likuiditas (current ratio) berpengaruh terhadap profitabilitas perusahaan manufaktur sub sektor pulp dan kertas. Menurut Riyanto (2013:25), Likuiditas diartikan sebagai kemampuan suatu perusahaan untuk memenuhi kewajiban keuangan yang harus segera dipenuhi. Likuiditas menunjukkan kemampuan perusahaan untuk menghasilkan kas dalam jangka pendek untuk memenuhi kewajibannya. Likuiditas bergantung pada arus kas perusahaan dan komponen aktiva lancar dan kewajiban lancarnya. Likuiditas tidak hanya berkenaan dengan keadaan keseluruhan keuangan perusahaan, tetapi juga berkenaan dengan kemampuannya untuk mengubah aktiva lancar tertentu menjadi uang kas. Perusahaan harus mengubah aktiva lancar tertentu menjadi kas untuk membayar kewajiban lancarnya, misalnya perusahaan perlu menagih piutang atau menjual persediaannya sehingga perusahaan memperoleh kas. Pihak yang paling 
berkepentingan terhadap rasio lancar adalah kreditor jangka pendek seperti pemasok. Jumlah kas dan jumlah persediaan dan piutang yang akan dikonversi menjadi kas merupakan sumber daya yang dimiliki oleh perusahaan untuk membayar kewajiban kepada kreditor jangka pendek. Koefisien regresi menunjukkan angka 3,697 dengan tanda negatif. Hal tersebut bisa berarti bahwa tingkat likuiditas tinggi dengan pengelolaan yang kurang baik bisa menimbulkan dana menganggur dan perusahaan bisa kehilangan kesempatan untuk menbisakan tambahan laba karena dana yang dimiliki tidak menghasilkan keuntungan sehingga tidak meningkatkan profitabilitas perusahaan. Perusahaan harus mempertahankan, menjaga dan mengelola tingkat likuiditasnya dengan baik. Semakin tinggi tingkat likuiditas dengan pengelolaan yang baik, risiko semakin kecil, maka semakin baiklah posisi perusahaan di mata kreditur. Hal ini sesuai dengan hasil penelian S. Chen dan H. W. Oetomo (2015), yang menyatakan bahwa likuiditas memiliki pengaruh terhadap profitabilitas. Hasil penelitian ini tidak mendukung hasil dari penelitian A. Wibowo dan S. Wartini (2012), yang menyatakan bahwa likuiditas tidak berpengaruh terhadap profitabilitas.

\section{Pengaruh Rasio Financial Leverage Terhadap Profitabilitas}

Hasil Penelitian ini menunjukkan bahwa variabel rasio financial leverage tidak berpengaruh terhadap profitabilitas perusahaan manufaktur sub sektor pulp dan kertas. Hal ini menunjukkan bahwa kenaikan financial leverage tidak bisa memengaruhi jumlah profitabilitas perusahaan manufaktur sub sektor pulp dan kertas. Perusahaan sampel tercatat menggunakan hutang sebagai sumber pendanaan rata-rata sebesar 50\%. Angka tersebut terhitung cukup rendah untuk memengaruhi profitabilitas perusahaan. Menurut Sartono (2011:120), leverage menunjukkan proporsi atas penggunaan utang untuk membiayai investasinya. Leverage bisa meningkatkan baik keberhasilan laba maupun kegagalan rugi manajerial. Semakin tinggi proporsi hutang dalam struktur modal perusahaan akan mengakibatkan semakin tinggi risiko, karena hutang akan membawa biaya tetap yang harus dibayar terlepas dari kinerja operasi. Perusahaan harus memperhatikan tingkat solvabilitasnya. Perusahaan bisa meningkatkan porsi sumber pendanaan melalui hutang jika perusahaan bisa mengelola sumber dana yang berasal dari hutang dengan baik dan digunakan untuk proyek investasi yang produktif, sehingga bisa memberikan pengaruh yang positif dan berdampak terhadap peningkatan profitabilitas perusahaan.

Namun, jika perusahaan tidak bisa mengelola dana yang diperoleh dari hutang secara produktif, hal tersebut bisa memberikan pengaruh negatif dan berdampak terhadap menurunnya profitabilitas perusahaan. Opsi sumber pendanaan lain juga harus diperhitungkan perusahaan untuk mengurangi dan tidak bergantung pada hutang yaitu dengan memaksimalkan penjualan saham perusahaan. Pihak manajemen perusahaan harus mampu memperbaiki kinerjanya sehingga pihak masyarakat publik percaya pada kemampuan perusahaan dalam operasinya, yang pada akhirnya masyarakat akan menanamkan dananya di Bursa Efek, sehingga tidak hanya mengandalkan hutang sebagai sumber dana. Hal ini didukung dengan hasil penelitian 
A. Wibowo dan S. Wartini (2012), yang menyatakan bahwa financial leverage tidak berpengaruh terhadap profitabilitas. Hasil penelitian ini tidak mendukung hasil penelitian dari S. Chen dan H. W Oetomo (2015), yang menyatakan bahwa financial leverage memiliki pengaruh terhadap profitabilitas.

\section{Pengaruh Perputaran Modal usaha, Rasio Likuiditas dan Rasio Financial Leverage Terhadap Profitabilitas}

Hasil dari penelitian ini menunjukkan bahwa perputaran modal usaha, rasio likuiditas dan rasio financial leverage secara bersama-sama berpengaruh terhadap profitabilitas perusahaan manufaktur sub sektor pulp dan kertas. Modal usaha erat hubungannya dengan operasi perusahaan sehari-hari, juga menunjukkan tingkat keamanan para kreditur terutama kreditur jangka pendek (Munawir, 2016:114). Likuiditas berhubungan dengan kemampuan perusahaan untuk memenuhi kewajiban finansialnya yang segera harus dipenuhi. Rasio likuiditas bisa menunjukkan tingkat risiko perusahaan, tingginya tingkat likuiditas berarti semakin rendahnya tingkat risiko yang dimiliki perusahaan yang akan membuat semakin baik posisi perusahaan di mata kreditur. Tingkat penggunaan utang akan memengaruhi rasio solvabilitas, semakin tinggi penggunaan utang maka semakin tinggi pula risiko perusahaan. Tingginya utang juga berdampak pada jumlah kewajiban dan biaya bunga yang akan memengaruhi tingkat profitabilitas perusahaan. Ketiga variabel ini mempunyai pengaruh terhadap sistem keuangan dan profitabilitas perusahaan karena saling memengaruhi. Perusahaan harus memperhatikan dan mengelola tingkat perputaran modal usaha, likuiditas dan leverage-nya agar bisa menjaga dan meningkatkan profitabilitas perusahaan. Hasil dari penelitian ini didukung dengan hasil penelitian yang dilakukan A. Wibowo dan S. Wartini (2012) serta S. Chen dan H. W. Oetomo (2015), yang menyatakan bahwa perputaran modal usaha, likuiditas dan financial leverage secara bersama- sama atau simultan berpengaruh terhadap profitabilitas perusahaan manufaktur sub sektor pulp dan kertas.

\section{Kesimpulan}

Berdasarkan hasil dan pembahasan di atas maka bisa ditarik kesimpulan dari penelitian ini sebagai berikut:

a. Variabel perputaran modal usaha (working capital turnover) tidak berpengaruh terhadap profitabilitas (ROA). Hal ini terjadi karena pengelolaan perusahaan yang kurang efisien sehingga tidak bisa meningkatkan atau mempengaruhi profitabilitas perusahaan.

b. Variabel rasio likuiditas berpengaruh terhadap profitabilitas (ROA) dengan nilai negatif. Hal ini berarti bahwa perusahaan dengan likuiditas yang tinggi akan menghasilkan profitabilitas yang rendah, karena semakin besar dana yang ditempatkan untuk memenuhi likuiditas perusahaan, maka perusahaan bisa kehilangan kesempatan untuk menbisakan tambahan laba karena dana yang dimiliki tidak menghasilkan keuntungan. 
c. Variabel rasio financial leverage tidak berpengaruh terhadap profitabilitas (ROA). Hal ini terjadi karena penggunaan hutang sebagai sumber pendanaan yang rendah tidak bisa memengaruhi profitabilitas.

d. Variabel perputaran modal usaha, rasio likuiditas dan rasio financial leverage secara bersama-sama berpengaruh terhadap variabel profitabilitas (ROA). Pengaruh dari variabel independen secara simultan terjadi karena masing- masing variabel independen (perputaran piutang, likuiditas dan leverage) memiliki hubungan dan saling mempengaruhi terhadap sistem keuangan dan profitabilitas perusahaan. 


\section{Bibliografi}

Abor, Joshua. 2005. The Effect of Capital Structure on Profitability: An Ampirical Analysis of Listed Firms in Ghana. The Journal of Risk Finance. 6(5): 438-445.

Brigham, Eugene F dan Houston. 2014. Dasar-Dasar Manajemen Keuangan. Jakarta: Salemba Empat.

Chen, Sylvia dan H. W. Oetomo. 2015. Pengaruh Leverage, Likuiditas dan Perputaran Modal usaha Terhadap profitabilitas. Jurnal Ilmu dan Riset Manajemen. 4(10).

Diana, P. A. Dan B. H. Santoso. 2016. Pengaruh Perputaran Kas, Piutang, Persediaan Terhadap Profitabilitas pada Perusahaan Semen di BEI. Jurnal Ilmu dan Riset Manajemen. 5(3).

Ghozali, Imam. 2013. Aplikasi Analisis Multivariate dengan Program IBM SPSS 19. Semarang: Badan Penerbit Universitas Diponegoro.

Gill, Amarjit dan Nahum Biger. 2011. The Effect of Capital Structure on Profitability: Evidence from The United States. International Journal of Management. 28(4).

Hastuti, Niken. 2010. Analisis Pengaruh Periode Perputaran Persediaan, periode Perputaran Hutang Dagang, Rasio Lancar, Leverage, Pertumbuhan Penjualan dan Ukuran Perusahaan terhadap Profitabilitas Perusahaan [Skripsi]. Semarang(ID): Universitas Diponegoro.

Iskandar, Tania, Emrinaldi Nur dan Edfan Darlis. 2014. Pengaruh Perputaran Modal usaha, Struktur Modal dan Likuiditas Terhadap Profitabilitas Perusahaan Industri dan Chemical di BEI. JOP FEKON. 1(2): 1-15

Kasmir. 2010. Analisis Laporan Keuangan. Jakarta: PT Raja Grafindo Persada.

Kementrian Perindustrian. 2017. "2017, RI Produsen Kertas Nomor 6 Terbesar di Dunia”. $\quad$ http://www.kemenperin.go.id/artikel/16596/2017,-RI-ProdusenKertas-Nomor-6-Terbesar-Dunia (16 Juli 2018)

Martono, Nanang. 2012. Metode Penelitian Kuantitatif: Analisis Isi dan Analisis Data Sekunder. Jakarta: PT Rajagrafindo Persada.

Munawir, S. 2016. Analisa Laporan Keuangan Cetakan Ketujuh Belas. Yogyakarta: Liberty.

Priyatno, Duwi. 2010. Paham Analisa Statistik Data dengan SPSS. MediaKom:Jakarta.

Putri, L.R. dan L. S. Musmini. 2013. Pengaruh Perputaran Kas Terhadap Profitabilitas pada PT Tirta Mumbul Jaya Abadi Singaraja Tahun 2008-2012. Jurnal Akuntansi Profesi. 3(2): 142-152.

Rahayu, E. A. Dan J. Susilowibowo. 2014. Pengaruh Perputaran Kas, Perputaran Piutang dan Perputaran Persediaan terhadap Profitabilitas Perusahaan Manufaktur. Jurnal Ilmu Manajemen. 2(4): 1444-1455.

Riyanto, Bambang. 2013. Dasar-Dasar Pembelanjaan Perusahaan. Yogyakarta: BPFE.

Sartono, Agus. 2011. Manajemen Keuangan Teori dan Aplikasi Edisi 4. Yogyakarta: BPEF-YOGYAKARTA. 
Analisis Modal Kerja, Likuiditas, dan Leverage Terhadap Profitabilitas Perusahaan

Siswanto, Agus. 2001. Analisis Pengaruh Modal usaha Terhadap Profitabilitas Perusahaan Manufaktur PMA dan PMDN yang Go Public di Bursa Efek Jakarta [Thesis]. Semarang (ID): Universitas Diponegoro.

Sunyoto, Danang. 2013. Metodologi Penelitian Akuntansi. Bandung: PT Refika.

Sugiyono. 2017. Metode Penelitian Pendidikan. Bandung: Alfabeta.

Tika, Pabundu. 2006. Metodologi Penelitian Geografi. Jakarta: Gramedia.

Van Horne, James C. dan John M. Wachowicz Jr. 2014. Prinsip-Prinsip Manajemen Keuangan. Jakarta: Salemba Empat.

Wibowo, S dan S. Wartini. 2012. Efisiensi Modal usaha, Likuiditas dan Leverage pada Perusahaan Manufaktur di BEI. Jurnal Dinamika Manajemen. 3(1): 49-58. 